\title{
A Significant Outcome of Work Life: Occupational Accidents in a Developing Country, Turkey
}

\author{
O. Alp ErgörR ${ }^{1}$, Yücel Demiral ${ }^{1}$ and Y. Bülent PiYaL ${ }^{2}$
}

${ }^{1}$ Department of Public Health, School of Medicine, Dokuz Eylül University and ${ }^{2}$ Ministry of Labour and Social Security, Turkey

\begin{abstract}
A Significant Outcome of Work Life: Occupational Accidents in a Developing Country, Turkey: O. Alp ERGör, et al. Department of Public Health, School of Medicine, Dokuz Eylül University, Turkey-Occupational accident rates are high in the developing world and they are among the crucial indicators of work life. The data on serious occupational accidents in three years from the Aegean Region of Turkey were analyzed in order to define the working life situation. The data for 1995-97 were obtained from The Social Insurance Institution. Variables were defined for workers, work environment and working conditions for descriptive analysis. The relationships between these variables and outcomes of the occupational accidents were analyzed. The fatality risk was 2.6 times higher for mining and construction than for the production sector $(p<0.001)$, and 1.6 times higher for evening and night shifts than for day shifts $(p<0.01)$. Mortality from being struck by something, falls, motor vehicle accidents and electrocutions were significantly higher than being cut or in, under or between objects (OR 3.5, 8.7, 23.1, 26.1 respectively and $p<0.01)$. As a conclusion, it was suggested that within the globalization picture, occupational health problems in the developing world should be explored intensively in order to establish effective prevention programs.

(J Occup Health 2003; 45: 74-80)
\end{abstract}

Key words: Occupational accidents, Work environment, Working conditions, Occupational health, Turkey

International Labor Organization's (ILO) projections point out that nearly $1 / 3$ of the occupational attributed deaths occur due to accidents ${ }^{1)}$. According to ILO figures approximately 250 million occupational accidents occur

Received March 7, 2002; Accepted Sep 24, 2002

Correspondence to: O. A. Ergör, Department of Public Health, School of Medicine, Dokuz Eylül University, Izmir, Turkey each year, with an overall fatality rate of 14.0 per hundred thousand. It is an important fact that this rate is underestimated as stressed in the same sources ${ }^{2,3}$. WHO and ILO have predicted significant worsening in occupational health indicators in the developing world. Technology transfer is thought to play a crucial role in this ${ }^{4-6)}$. The developing world comprises $60 \%$ of the global workforce and $80 \%$ of this workforce is employed in small-scale enterprises and the informal sector which involve inherently heavy and dangerous work ${ }^{1,7)}$. Only $5-15 \%$ of this population has access to any form of occupational health service. In this context it is possible to say that traditional occupational problems such as industrial accidents and occupational diseases would remain important in terms of priority in the contemporary era. Turkey's occupational health problems are quite similar to the picture drawn by ILO and WHO. According to the national statistics, the accident frequency rate is 14.3 per thousand, the fatal accident rate is 13.9 per hundred thousand and the accident fatality rate is 976.7 per hundred thousand; and from all causes the fatality rate was 22.3 per hundred thousand in $2000^{8}$. But the denominator of these indicators (rates) is not the country's 23 million economically active population, but 6 million workers covered by the compulsory Social Insurance system for employees.

Industrial accidents are crucial in determining the indicators of work life ${ }^{9,10)}$. The objective of this study was to examine the notified occupational accidents in 3 years within the workforce, work environment and working conditions.

\section{Methods}

In Turkey data from The Social Insurance Institution (SII) provide the most reliable and complete information on industrial accidents. But workers who are in the informal sector, agriculture, white collar workers in government offices, seafarers and self employed are not covered in this surveillance system. Employers are 
Table 1. Occupational health indicators for Turkey and the Aegean Region of Turkey $\left(^{*}\right)$.

\begin{tabular}{lcccc}
\hline Location & $\begin{array}{c}\text { Number of } \\
\text { enterprises }(\times 1,000)\end{array}$ & $\begin{array}{c}\text { Distribution of small } \\
\text { scale enterprises** }(\%)\end{array}$ & $\begin{array}{c}\text { Number of employees } \\
\text { under SII }(1,000)\end{array}$ & $\begin{array}{c}\text { Percentage of employees }(\%) \\
\text { covered by SII in total population }\end{array}$ \\
\hline Aegean Region & 119.0 & 73.0 & 759.0 & 9.8 \\
Turkey & 753.0 & 98.0 & $5,254.1$ & 7.8 \\
\hline
\end{tabular}

\begin{tabular}{lcc} 
& \multicolumn{2}{c}{ Occupational Accident Indicators } \\
\cline { 2 - 3 } & Fatality Rate $\left(10^{-5}\right)$ & Deaths (no) \\
\cline { 2 - 3 } Aegean Region & 46.6 & 351 \\
Turkey & 22.3 & 1,173 \\
\hline
\end{tabular}

\begin{tabular}{lcc} 
& \multicolumn{2}{c}{ Unionization } \\
\cline { 2 - 3 } & Unionized workplaces \% & Unionized workers $\%$ \\
\cline { 2 - 3 } Aegean Region & 7.0 & Unknown \\
Turkey & 11.7 & $56.8^{* * *}$ \\
\hline
\end{tabular}

*Source: Statistical Yearbook 2000, Turkish Republic Social Insurance Institution, 2001.

***Workplaces with less than 49 workers

****The unionization ratio was declared to be $16.6 \%$ according to the Yearbook For 97-99 of the Petroleum, Chemical and Rubber Workers' Union of Turkey.

Table 2. Variables used in the analysis

\begin{tabular}{ll}
\hline Employee & Age: (child workers 18 and less; old age 45 and over; young and middle age 19-44) \\
& Sex \\
\hline Work Environment & $\begin{array}{l}\text { Size of the enterprise: (employs } 49 \text { or fewer than } 49 \text { workers; employs } 50 \text { workers or more) } \\
\text { Economic activity: Service, production, mining and quarrying, construction } \\
\text { Type of accident: Struck by or against; cut in, under or between (CIUB); falls from or at any } \\
\text { level; motor vehicle; explosions; all others }\end{array}$ \\
\hline Working Conditions & $\begin{array}{l}\text { Days : Weekdays, weekends } \\
\text { Daily work hours: } 8 \text { h of work/d, overtime (9 h or more/d) } \\
\text { Shift: Day 09.00-17.00, evening 18.00-24.00, night } 00.00-08.00\end{array}$ \\
\hline Outcome & Death and all other injuries \\
\hline
\end{tabular}

obliged to report all accidents to the SII within 2 days. Labour Inspectors from the Ministry of Labour and Social Security (MLSS) have to conduct an investigation at the accident site. The Labour Inspectorate investigates only accidents that result in death, loss of an organ or long term hospitalization, which are classified as serious accidents. This study was conducted on the 1995-1997 data on serious accidents from the six provinces in the Aegean Region.

The Aegean Region is one of the leading areas of the country in terms of production and commerce, and is densely populated with $11.5 \%$ of Turkey's population. The workforce covered through the compulsory Social
Insurance System is $14.5 \%$ of the country's total. The Aegean Region's and Turkey's fundamental occupational health indicators are shown in accident analysis covered employees' age and sex, work environment (enterprise size-number of employees, economic activity or sector, type of accident), working conditions (days, hours of work and shift work) and outcomes (death or injury). The type of accident is an indicator of the risk that the workers are exposed to; therefore it was considered as a work environment variable (Table 2). Types of the accidents were classified according to the "International Labour Organization Bureau of Statistics Classification of Industrial Accidents According To Type of Accident" 
Table 3. Percent distribution of accidents during 1995-1997 in the Aegean Region according to the study variables, Turkey

\begin{tabular}{|c|c|c|}
\hline Demographic Characteristics of Employees & $\%$ & $\mathrm{n}$ \\
\hline \multicolumn{3}{|l|}{ Gender } \\
\hline Female & 6.0 & 101 \\
\hline Male & 93.9 & 1,590 \\
\hline Unknown & 0.1 & 3 \\
\hline \multicolumn{3}{|l|}{ Age Groups } \\
\hline$<=18$ & 8.8 & 149 \\
\hline $19-44$ & 78.3 & 1,327 \\
\hline $45+$ & 12.9 & 218 \\
\hline \multicolumn{3}{|l|}{ Characteristics of Work Environment } \\
\hline \multicolumn{3}{|l|}{ Numbers of Employees } \\
\hline$<50$ & 63.2 & 1,071 \\
\hline$>=50$ & 28.9 & 489 \\
\hline Unknown & 7.9 & 134 \\
\hline \multicolumn{3}{|l|}{ Economic Activity } \\
\hline Mining and quarrying & 11.8 & 199 \\
\hline Production & 52.0 & 882 \\
\hline Construction & 23.1 & 391 \\
\hline Services & 11.5 & 212 \\
\hline Unknown & 1.6 & 10 \\
\hline \multicolumn{3}{|l|}{ Type Of Accident } \\
\hline Caught in, under or between something & 35.6 & 603 \\
\hline Fall at the same level or from an elevation & 21.0 & 355 \\
\hline Struck by or struck against & 15.3 & 259 \\
\hline Motor vehicle accidents & 10.8 & 183 \\
\hline Electrocution & 6.0 & 102 \\
\hline All others* & 9.5 & 161 \\
\hline Unknown & 1.8 & 31 \\
\hline \multicolumn{3}{|l|}{ Characteristics of Working Conditions } \\
\hline \multicolumn{3}{|l|}{ Accident Day } \\
\hline Week Days & 79.5 & 1,345 \\
\hline Weekends & 16.8 & 286 \\
\hline Unknown & 3.7 & 63 \\
\hline \multicolumn{3}{|l|}{ Daily Working Hours } \\
\hline 8 hours work/day & 90.5 & 1,533 \\
\hline Overtime & 5.0 & 84 \\
\hline Unknown & 4.5 & 77 \\
\hline \multicolumn{3}{|l|}{ Shift Work } \\
\hline Day shift & 61.1 & 1,035 \\
\hline Evening & 15.6 & 265 \\
\hline Night & 11.1 & 188 \\
\hline Unknown & 12.2 & 206 \\
\hline \multicolumn{3}{|l|}{ Outcomes } \\
\hline Fatal accidents & 20.7 & 351 \\
\hline Injuries & 79.3 & 1,343 \\
\hline TOTAL & 100.0 & 1,694 \\
\hline
\end{tabular}

*Includes explosions, contact with chemical or physical agents, drowning. 
Table 4. Percent distribution of fatal and nonfatal accidents during 1995-1997 in the Aegean Region according to the study variables, Turkey.

\begin{tabular}{|c|c|c|}
\hline Variables & $\begin{array}{l}\text { atal accidents* } \\
\text { n: } 351\end{array}$ & $\begin{array}{c}\text { Non-fatal accidents* } \\
\text { n: } 1343\end{array}$ \\
\hline \multicolumn{3}{|l|}{ Age Groups ${ }^{\mathrm{a}}$} \\
\hline$<=18$ & 7.7 & 9.1 \\
\hline $19-44$ & 78.6 & 78.2 \\
\hline$>=45$ & 13.7 & 12.7 \\
\hline \multicolumn{3}{|l|}{ Enterprise Size } \\
\hline$<50$ & 27.6 & 32.3 \\
\hline$>=50$ & 72.4 & 67.7 \\
\hline \multicolumn{3}{|l|}{ Type of Accident ${ }^{b}$} \\
\hline Struck by & 7.5 & 17.7 \\
\hline CIUB & 5.2 & 44.4 \\
\hline Falls & 29.2 & 19.3 \\
\hline Motor vehicle & 26.3 & 7.0 \\
\hline All others & 31.8 & 11.6 \\
\hline \multicolumn{3}{|l|}{ Economic Activity ${ }^{b}$} \\
\hline Production & 25.0 & 59.5 \\
\hline Service & 19.5 & 10.8 \\
\hline Mining and quarrying & 18.4 & 10.1 \\
\hline Construction & 37.1 & 19.6 \\
\hline \multicolumn{3}{|l|}{ Work Days ${ }^{\mathrm{a}}$} \\
\hline Weekdays & 81.4 & 82.7 \\
\hline Weekends & 18.6 & 17.3 \\
\hline \multicolumn{3}{|l|}{ Daily Working Hours ${ }^{b}$} \\
\hline 8 hours work/day & 91.3 & 95.7 \\
\hline Overtime & 8.7 & 4.3 \\
\hline \multicolumn{3}{|l|}{ Shift Work ${ }^{b}$} \\
\hline Day shift & 59.7 & 72.0 \\
\hline Evening and night shift & 40.3 & 28.0 \\
\hline
\end{tabular}

a:p $>0.05$, b: $p<0.01,{ }^{*}$ Column percentage

Accidents were classified as "struck by or against", "cut in, under or between" (CIUB), "falls from or at any level", "motor vehicle accidents", "explosions" and "all others". The MLSS's List of Sectors of Industry was used to determine the sector. The SPSS 11.0 software package was used for analysis. Univarite analysis (chi-square test) was done to define statistical differences between fatal and non-fatal (serious) accidents according to study variables. As the next step in the analysis, logistic regression was used to define the risk of fatality, adjusting for all known risk factors which may effect as confounding variables.

\section{Results}

Total numbers of accidents were 1694 between 1995 and 1997. Among them 351 (20.7\%) were fatal. The average occupational accident rate was 79.2 per hundred thousand, and the fatality rate was 16.4 per hundred thousand for the 3 year period (1995-1997). As seen in Table 3, of the workers involved in the accidents $93.9 \%$ were male. Mean age was 32.3 (SD 10.7). Approximately $30 \%$ of the child worker cases were reported from construction, mining and quarrying sectors. Age groups which were considered under the high risk for occupational accidents, such as child workers and aged workers, constituted $21.7 \%$ of all cases.

Among the enterprises $63.0 \%$ employed less than 50 workers (small scale enterprises). Approximately half of those in the study group (43.0\%) were from workplaces with less than 9 employees. Reported occupational accidents mainly came from three sectors, production $52.0 \%$, construction $23.1 \%$ and mining and quarrying $11.8 \%$. The majority $(35.6 \%)$ of the accidents were in the "CIUB" category and $21.0 \%$ were falls. Of all accidents, $16.8 \%$ occurred during the weekends, $5.0 \%$ during overtime work and $26.7 \%$ during evening and night shifts.

The distribution of fatal accidents and injuries did not show any significant differences according to age group, size of the enterprise or working days $(p>0.05)$, but working in the evening and night shift, overtime work, and sectors other than production resulted in significantly higher fatal accidents $(\mathrm{p}<0.05)$. Fatal accidents were seen more frequently in accident types other than CIUB and struck by something $(\mathrm{p}<0.01)$.

Although univariate analysis revealed statistical differences for only four variable groups (type of accident, economic activity, daily working hours and shift workTable 4) other variables considered as having a confounding effect were included in the logistic regression model in order to define the risk of a fatality. Only the type of accident, economic activity and shift work were present in the reduced model (Table 5). When CIUB was defined as a reference category, the odds ratios were 3.5 for struck by something (95\% CI 1.7-7.1), 8.7 for falls (95\% CI 4.5-16.6), 23.1 for motor vehicle accidents (95\% CI 11.8-45.3), 26.1 for electrocution (95\% CI 12.3-55.4) and 9.9 for all others (95\% CI 5.019.6) including explosions, drowning, or contact with chemical agents. Under the economic activity category, the odds ratio for mining was 2.5 (95\% CI 1.6-4.1) and for construction 2.6 (95\% CI 1.6-4.0) compared to the production sector. Night and evening shifts were grouped together for logistic regression, and the odds ratio was 1.6 (95\% CI 1.1-2.3) when day shift was taken as the reference. 
Table 5. Risk factors related to fatal injuries: Results of logistic regression

\begin{tabular}{|c|c|c|c|c|}
\hline & Categories & $\mathrm{p}$ & Odds Ratio & $95 \% \mathrm{CI}$ \\
\hline \multicolumn{5}{|l|}{ Full model } \\
\hline Sex & Male & 0.164 & 1.60 & $0.82-3.11$ \\
\hline \multirow[t]{4}{*}{ Age group } & & 0.198 & & \\
\hline & $19-44$ & & Ref. & \\
\hline & $18 \&$ less & 0.245 & 1.43 & $0.78-2.60$ \\
\hline & $45+$ & 0.218 & 0.75 & $0.47-1.18$ \\
\hline Enterprise Size & $<50$ & 0.642 & 1.10 & $0.75-1.58$ \\
\hline \multirow[t]{5}{*}{ Economic Activity } & & 0.000 & & \\
\hline & Production & & Ref. & \\
\hline & Mining & 0.000 & 2.50 & $1.55-4.01$ \\
\hline & Construction & 0.000 & 2.41 & $1.53-3.79$ \\
\hline & Service & 0.155 & 1.46 & $0.86-2.44$ \\
\hline \multirow[t]{7}{*}{ Type of Accident } & & 0.000 & & \\
\hline & CIUB & & Ref. & \\
\hline & Struck & 0.000 & 3.62 & $1.79-7.29$ \\
\hline & Falls & 0.000 & 9.05 & $4.72-17.32$ \\
\hline & Motor v. & 0.000 & 24.56 & $12.40-48.61$ \\
\hline & Electrocutions & 0.000 & 26.10 & $12.26-55.47$ \\
\hline & Others & 0.000 & 10.60 & $5.31-21.04$ \\
\hline Work Days & Weekends & 0.425 & 1.20 & $0.78-1.78$ \\
\hline Daily Working Hours & Overtime work & 0.935 & 0.97 & $0.43-2.13$ \\
\hline Shift Work & Evening and night & 0.010 & 1.65 & $1.13-2.41$ \\
\hline \multicolumn{5}{|l|}{ Reduced model } \\
\hline \multirow[t]{5}{*}{ Economic Activity } & & 0.000 & & \\
\hline & Production & & Ref. & \\
\hline & Mining & 0.000 & 2.58 & $1.61-4.11$ \\
\hline & Construction & 0.000 & 2.61 & $1.68-4.03$ \\
\hline & Service & 0.140 & 1.46 & $0.88-2.42$ \\
\hline \multirow[t]{7}{*}{ Type of Accident } & & 0.000 & & \\
\hline & CIUB & & Ref. & \\
\hline & Struck & 0.000 & 3.58 & $1.78-7.17$ \\
\hline & Falls & 0.000 & 8.71 & $4.56-16.62$ \\
\hline & Motor v. & 0.000 & 23.15 & $11.83-45.30$ \\
\hline & Electrocutions & 0.000 & 26.17 & $12.35-55.43$ \\
\hline & Others & 0.000 & 9.91 & $5.00-19.61$ \\
\hline Shift Work & Evening and night & 0.005 & 1.67 & $1.16-2.39$ \\
\hline
\end{tabular}

\section{Discussion}

The study database consisted of industrial accidents reported with an outcome defined as death or serious injury during 1995-1997 in the Aegean Region of Turkey. Accident surveillance system and inspections of accidents are restricted to serious accidents which result in death, loss of an organ or a long period of hospitalization. Nonetheless, the main constraint about this system is that reporting is carried out mainly by considerably bigger enterprises which operate in the formal sector. Even though, almost $2 / 3$ of cases in the data reported from 
small scale enterprises, loss of near misses and small accidents indicate a serious limitation to the interpretations. Despite the restrictions inherent to the data base, as Lortie and Rizzo point out in their comprehensive article, accident information "deserves closer attention" that might give some useful clues to define priorities and strategies for prevention ${ }^{2,10,12)}$.

High risk groups consisted of $1 / 5$ of the study population, and among them almost $1 / 3$ of the child worker cases were reported from high risk sectors (construction, mining and quarrying sectors) ${ }^{13,14)}$. These findings underline an important priority situation from the national protection programs perspective.

Although half of the cases were from workplaces with less than 9 employees, distribution of fatal accidents according to the size of the enterprise was not significantly different (Table 4, p>0.05). Most of the small scale enterprises carry on their activities in the informal economic sector, and underreporting is more frequent in these enterprises. Therefore, the differences in fatal accidents could be diminished.

The fatal accident distribution according to working time was a significant finding. Working time was discussed under three categories: the hours of work during the working days, shift work and the day of the week. $8.7 \%$ of fatal accidents occurred during overtime work ( 9 or more work hours per day) $(\mathrm{p}<0.01), 40.3 \%$ during evening or night shifts $(\mathrm{p}<0.01)$, but distribution was not significantly different on weekdays from that on weekends. Overtime work or night work is an important risk factor for getting injured at work ${ }^{15)}$. With the increased labour flexibility and deregulation, it is possible to see more employees working overtime or at evening and on night shifts ${ }^{16,17)}$. Multivariate analyses reveal that night and evening shifts have a 1.6 times greater fatality risk than day shifts. This fact indicates that prevention strategies should be studied for the changes of working conditions.

High odds ratios with solid confidence intervals showed that accident types with well known universal precaution procedures, such as falls, motor vehicle accidents and electrocutions were among the leading causes of death, which is consistent with the literature ${ }^{18-20)}$.

Contrary to reports in the literature ${ }^{19,20)}$ CIUB cases were only $5.2 \%$ of fatal accidents. This could be explained by the fact that CIUB accidents are quite different in developing countries than reported for the developed world. Small scale workplaces, which were mainly in the production sector, reported most of the CIUB cases. In small enterprises, the extremities were caught in, under or between machinery parts or operation points, which would result in a serious accident such as amputation rather than death. Due to the nature of CIUB cases in Turkey, they are considered as a reference category for fatal accidents in logistic regression. Motor vehicle accidents and electrocutions have a tremendously high risk of fatality (OR 24.5 and 26.1).

The construction sector continues to be an important risk factor for fatal accidents ${ }^{2,8)}$. Lack of effective prevention procedures could cause a higher fatality rate in this sector. Half of the accidents were reported from production $(52.0 \%)$ and almost $1 / 4$ from the construction sector. Construction and mining cases were almost 2.5 times as fatal as the production sector (95\% CI: $1.6-4.1$ and 1.6-4.0). Considering the distribution of small scale enterprises, it is consistent to find more fatal accidents in these labour intensive sectors ${ }^{4,20,21)}$.

In developing countries, despite the limitations to the data quality, analysis of routine data may still reveal important information ${ }^{22)}$. Exploration of three years of serious industrial accidents, in the context of worker, work environment and working conditions, emphasized some important key points. Most of the accidents were preventable with the implementation of existing regulations and rational utilization of resources. In the context of globalization it is expected that the share of small size enterprises will be growing and flexible production will be more common. Therefore, if precautions were not considered immediately, the effect will be seen as worsening of occupational accident indicators.

Acknowledgments: We would like to express our deepest appreciation to Yaşar Alkan from the Regional Occupational Health and Safety Laboratory (ISGÜM) and to Dr.Gül Ergör from Department of Public Health for her invaluable comments and for reviewing the manuscript.

\section{References}

1) Takala J. Introductory Report Of The International Labour Office. Occupational Safety and Health Branch International Labour Office, Geneva 1999.

2) Takala J. Global estimates of fatal occupational accidents. Sixteenth International Conference of Labour Statisticians. ICLS/16/RD 8, ILO, Geneva 1998.

3) Takala J. Indicators of death, disability and disease at work, SafeWork: The Global Programme on Safety, Health and the Environment. African Newsletter on Occupational Health and Safety 9, 60-65 (1999)

4) Goldstein G, Helmer R, Fingerhut M. Mobilizing to project worker's health: The WHO Global Strategy on Occupational Health and Safety. African Newsletter on Occupational Health and Safety 2001; 11: 56-60.

5) Global Strategy on Occupational Health for All: The Way to Health at Work Recommendation of the Second Meeting of the WHO Collaborating Centers in Occupational Health, Beijing, China, 1994.

6) The Burden Of Occupational Illness: UN Agencies Sound the Alarm. Press Release WHO/31, 8 June 1999.

7) Occupational Health: Ethically Correct, Economically 
Sound. WHO Fact Sheet N84, 2000.

8) Number of Work Places And Insured Persons in Statistical Yearbook 2000. Turkish Republic Social Insurance Institution, 2001. (http://www.ssk.gov.tr/ istatistik/)

9) Rantannen J, Kauppinen T, Toikkanen J, et al., eds. Accidents at work. In: Work and health country profiles: Country profiles and national surveillance indicators in occupational health and safety. Finnish Institute of Occupational Health, Helsinki 2001; 4248.

10) Jorgensen K. Audits, Inspections and Investigations: Reporting And Compiling Accident Statistics. In: ILO Encyclopedia of Occupational Health and Safety, ILO, Geneva 2, 1-31 (1998)

11) Meeting of Experts on Labour Statistics: Occupational Injuries. Bureau of Statistics, International Labour Organization, Geneva, 1998.

12) M Lortie and P Rizzo. The classification of accident data. Safety Science 31, 31-57 (1999)

13) Forastieri V. Current Legislation and Child Labour. In: Children at Work: Health and safety risks. ILO, 1997; 2-6.

14) The Aging worker. In: Aging and Working Capacity. Report of a WHO Study Group. WHO technical report series 835, ILO, Geneva 1993; 3-4.

15) Ergör A. Analysis of Occupational Accidents Between 1994-1996 in Four Enterprises of Machinery and Chemical Institution. Dissertation, Institute of Health
Sciences, Hacettepe University, Ankara, Turkey, 1997.

16) H Frumkin. Across the Water and Down the Ladder: Occupational health in The Global Economy. Occup Med (Lond): State of the Art Reviews 14, 637-663 (1999)

17) Walters D. Health and Safety Strategies in a Changing Europe. Int J Health Serv 28, 305-331 (1998)

18) J Zhu, Z Xia, D Christiani, GS Sorock, T Ye, TK Courtney, T Zhu, Q Wu and H Fu: Fatal Occupational Events in a Development Area in East China: 1991 to 1997. J Occup Health 42, 276-280 (2000)

19) Amweelo M. Accident prevention in Namibia. African Newsletter on Occupational Health and Safety 10, 4-8 (2000)

20) Keyserling WM. Occupational Safety: Prevention of Accidents and Overt Trauma. In: Levy BS, Wegman DH, ed.. Occupational Health, Recognizing and Prevention Work-Related Disease. Little, Brown and Company, Third Ed. 1995; 145-159.

21) Richardson D, Loomis D. Trend in Fatal Occupational Injuries and Industrial Restructuring in North Carolina in the 1980s. Am J Public Health. 87, 1041-1043 (1997).

22) Smith GS, Veazie MA. Accident Prevention: Principles Of Prevention: The Public Health Approach To Reducing Injuries In The Workplace. In: ILO Encyclopedia of Occupational Health and Safety, ILO, Geneva 2, 1-42 (1998) 